\title{
Flexible kinship: shaping transnational families among the Chinese in Tahiti
}

\author{
Anne-Christine Trémon Université de Lausanne
}

\begin{abstract}
This article examines the practices of 'flexible kinship' used by Chinese migrants in colonial Tahiti. 'Flexible kinship' draws attention to the strategic uses that are made of kinship in the context of migration and diaspora: the adjustments to cultural, political, and legal borders that lead to changes in family forms and in the relations between kin. Using a multi-generational perspective, I examine how families were shaped by successive changes and reversals in legal-political and economic events and conjunctures over the long twentieth century. I argue for the importance of addressing transnational border-crossing practices that involve not just a spatial extension of networks but also legal strategies within the host locality. I further show that if it is true that the Confucian hierarchical order has conditioned transnational practices of flexible kinship, then this hierarchy has not only bent to the circumstances, it has to a great extent been weakened. Finally, I argue that the history of familial adjustments has shaped a habitus that maximizes economic and legal security, especially among women.
\end{abstract}

In recent years, the field of transnational studies has breathed new life into the study of kinship, a field that anthropologists had abandoned only for it to become occupied by social historians (Kuper 2008). Understanding what takes place within the family unit has been central to the work of a number of scholars who have retraced the formation of spatially dispersed family networks (Bryceson \& Vuorela 2002; Chamberlain \& Leydesdorff 2004; Olwig 2007; Parreñas 2005; Razy \& Baby-Collin 2011; Waters 2005). There have been calls for more longitudinal studies (Huang, Yeoh \& Lam 2008), especially regarding the maintenance of transnational networks among the second and later generations. Some have also pointed to the importance of addressing how broader institutional landscapes can shape the practices of migrant families (Landolt \& Da 2005; Levitt \& Glick Schiller 2004). While considerable attention has been paid to how family ties are maintained and transformed as a result of dispersions in space, the strategic use of legal tactics has received less consideration (De Hart, van Rossum \& Sportel 2013; Menjivar 2012). In this article, I take up these challenges through the case of Chinese migrants in colonial Tahiti (known today as French Polynesia) and their descendants. I examine their practices of what I call 'flexible kinship': that is, the (re)location of family members across national borders in both geographic and legal space. ${ }^{1}$ 
Flexible kinship is also an expansion of Aihwa Ong's notion of 'flexible citizenship', which she describes as 'the strategies and effects of mobile managers, technocrats and professionals seeking to both circumvent and benefit from different nation-state regimes by selecting different sites for investments, work and family relocation' (1999: 112; emphasis in original). She traces the roots of this 'modern Chinese transnationalism' back to the late nineteenth century, a time when overseas Chinese traders, transgressing the localizing regimes of colonial powers, developed a 'family-centred notion of Confucianism' emphasizing filial piety (1999: 114-15). 'Flexible citizenship' is meant to highlight how this 'regime of diasporan Chinese kinship' interacts with the contemporary regimes of the nation-state and of the marketplace.

While Ong's conceptualization of 'flexible citizenship' is extremely valuable in highlighting how relations between kin are used strategically for purposes of capital accumulation, it is built upon a view of kinship that is, paradoxically, 'inflexible'. Ong as well as Greenhalgh (1994) and Ong and Nonini (1997) have levelled a much-needed critique of the glorification of 'Confucian' capitalism and particularly of the Chinese family firm, showing how this is at once a discourse that masks and a culturalist explanation that overlooks power differentials and the exploitation of family members - particularly younger sons and women. However, while they stress the instrumentalization of Confucian values, they seem to assume that these remain unchallenged. This is at least the impression that one can derive from their evocation of a 'long-standing habitus' of family relations (Ong \& Nonini 1997: 21), and of a 'cultural logics of transnationality' or 'Confucian ethics' on which the 'family governmentality' is based (Ong 1999: 118). Susan Greenhalgh, for her part, acknowledges that her focus is 'not on women's agency in resisting structures of domination, but on men's agency in creating and reproducing those structures of domination' (1994: 748).

'The ideas that underlay the daily practice of the Chinese family system can ... with some justice be labelled "Confucian", as historian Patricia Ebrey (2000: ix) writes regarding late imperial China - it is at the end of this period that large-scale overseas Chinese migration started. The Confucian model rests on the intersection of two sets of hierarchical relations: one based on the order of birth, which governs the relations between generations and between siblings; the other based on gender, which frames the statuses of wives and daughters (Liu 1959: 47-8). These dual hierarchies condition relations between kin and constitute the framework in which families are formed and unfold. However, flexible kinship is meant to emphasize that not only are kinship relations central to the workings of flexible capitalism, but kinship itself is adjustable. Moreover, not only do these hierarchies bend according to the circumstances, but the flexible uses themselves have further altered them, especially as regards gender. Indeed, my research findings support reappraisals of the place of women in the Chinese family that emphasize the practical importance of uterine ties and challenge the androcentric vision of the patriarchal order (Brandtstädter \& Santos 2009; Gallin 1966; Stafford 2000; Wolf 1972; Yan 1996).

I therefore start from another direction by looking at kinship from a practical and processual point of view. Flexible kinship is an extension of Pierre Bourdieu's (1990 [1980]) concept of parenté pratique, or 'practical kinship'. He distinguishes it from 'official kinship', the ideal view of family relations that anthropologists tend to take for granted when they approach kinship as a rules-bound system rather than as a set of practices that strategically play with rules. Bourdieu's work reflects a larger shift to a 
relational approach to kinship (as anticipated by Mitchell 1969; and developed later by Carsten 2004 and Lambek 2011). ${ }^{2}$ He thereby introduces a practice-based approach to kinship that regards it not as an autonomous sphere, but as related to other aspects of social relations by the uses that are made of it. Likewise, flexible kinship consists of a set of practices that use kin relations as a resource that can be mobilized in larger social fields. It mobilizes kin to adjust to local and global political-economic conjunctures, and differentiated opportunities of acquiring cultural, political, economic, and legal capital.

Furthermore, flexible kinship calls forth a processual approach (Yanagisako 1975; 1979: 169) that views 'so-called nuclear relations as precipitates within larger networks and dynamics of kinship' (Lambek 2011: 5) and addresses social reproduction in all phases of the life-cycle, from birth to succession. The family unit can take several aspects over time (conjugal, joint, extended), and it unfolds and changes along with the family development cycle (Goody 1958; 1983). ${ }^{3}$ The Chinese Mandarin term for family, jia, has been defined by Myron Cohen as 'the group of persons who not only have kin ties to each other, but also a series of claims of one sort or another to the jia as an estate' (1976: 59). Fenjia, family property division, is the axis around which the family cycle develops (Cohen 1970; 1976). There is thus a disjunctive tendency that is inherent in family's logic of functioning - its development cycle. Family adjustments, aimed at strategies of economic and cultural capital accumulation, intensify and accelerate family division, and thus the development cycle.

In French Polynesia, the family and the enterprise merge to the point where the Chinese tend to designate one another by the name of their shop or business rather than their personal or family name. This suggests an ontological conflation of the kind Marshall Sahlins (2013) has highlighted with the notion of 'mutuality of being': the collective, solidary unit that family members form as they participate in each other's existence. Yet I will show how this very principle of working for the familial good implies differentiated investments in some siblings and sacrifices on the part of others that draw attention to the inherent contradictions of familial arrangements and the ambivalent valence of kinship relations. The ideal view that 'everyone works for the family as a whole' is therefore not so much 'false' in that it masks exploitation and economic inequalities (Greenhalgh 1994: 750); rather, it is what renders them possible. A diachronic approach offers a new perspective on 'the gradations and accumulations of kinship as well as its ruptures and dissolution', not just attachment, but also separation (Carsten 2013: 248; see also Lambek 2011). It further shows how family developments result both from the intentions of their members and from the social and economic environment (Bruguière 2002). Using a multi-generational perspective, I analyse how the practices of flexible kinship have served strategies of capital accumulation in response to fluctuations both in legal and political immigration regimes and in economic opportunities over several generations.

Transnational studies (Glick Schiller, Basch \& Blanc-Szanton 1992; Kearney \& Nagengast 1989; Portes, Guarnizo \& Landolt 1999; Rouse 1991; Smith \& Guarnizo 1998) have been critiqued on several key grounds. In particular, they have been taken to task for over-emphasizing a rupture with the past (Friedman 2004; Morawska 2001; Waldinger \& Fitzgerald 2004) and for a lack of clarity in defining the specific features of transnationalism. Waldinger and Fitzgerald suggest an alternative approach that emphasizes the interactions of migrants with states: 'States make migrations international by bounding territories and defining the nations they seek to enfold' 
(emphasis in original). However, their interests remain in the 'constitutive aspects of movement across borders' (2004: 1188).

Yet, examining the intersection between state policies of nation-building and migrant practices involves more than looking at population movement. On the one hand, flexible kinship examines the practices of relocation of family members in different places, motivated by the expected benefits of this varied dispersion. But on the other hand, it encompasses a second set of practices that determine not their location in space, but their legal status (although one can imply the other). Among the Chinese in French Polynesia, it was, in particular, a matter of legal recognition of family members that amounted to a difference in legal status: that is, in citizenship. This practice was especially salient when it came to daughters, who thereby became French nationals. These practices were transnational in that they exploited the legal spaces that articulate birth (and thus kinship) and citizenship, since the latter results largely from filiation. ${ }^{4}$ Transnational practices, then, are not necessarily translocal. In making this distinction, the concept of flexible kinship moves beyond the preoccupation within transnational studies with movement or dispersal in space. In addition, the shift highlights the importance of addressing practices that involve not just a spatial extension of networks, but also practices that cross legal boundaries within the host locality itself (boundaries resulting from the categorization as alien within the host country).

These legal manoeuvres seek to evade constraints and also to accumulate a variety of resources - different kinds of capital - through the exploitation of differentials in regimes of citizenship and in economic contexts. Contexts mutate; studying how transnational families are formed and evolve over time requires focusing on temporal variation in economic and political constellations shaping the environment for social action (Waldinger \& Fitzgerald 2004: 1188). Flexible kinship practices result from and respond to discrepancies between the migrants' own temporalities, their perspectives, life trajectories, and family dynamics across generations and the temporality of global capitalism and geopolitical relations, which influences local regimes of citizenship and policies towards migrants and their descendants.

The historical period considered here is marked by a transition from a situation in which Chinese immigrants migrated into a French colonial society to one in which their third- and fourth-generation descendants are now members of an ethnic minority in a French overseas territory endowed with a very large degree of political autonomy. As part of the large wave of Chinese migration to the Pacific region, the Americas, and the colonies of Southeast Asia - one of the largest in human history - around 5,000 immigrants arrived in the Établissements Français de l'Océanie (EFO) between 1890 and 1930..$^{5}$ They settled on Tahiti, where they formed an urban community in the capital Papeete, but they also migrated to the rural districts and to other islands. They were registered and given a number upon arrival. These registers shows that, by 1948, only about half of them had remained in the colony. ${ }^{6}$

France did not apply jus soli (citizenship based on birth) in its colonies and overseas territories, which constituted a regime of exception within the French Republic. ${ }^{7}$ The children of Chinese immigrants born in the colony remained Chinese. Therefore, after immigration came to a halt in the mid-1930s, the Chinese population continued to grow internally and reached around 6,000 people in the 1960s. A change occurred only in 1973 when all Chinese were granted French citizenship, in accordance with a decree that extended French citizenship law to French overseas territories. Today, the third- and fourth-generation descendants of migrants are categorized as belonging to 
an ethnic minority in a French overseas territory where the political debate is very much structured around the issue of autonomy versus independence.

My aim is to show - through an analysis of family trajectories across several generations and an outline of recurrent schemes of practices - how discrepancies between the temporal horizons of individuals and families and economic and political conjunctures have shaped flexible kinship. I further argue that successive changes and reversals in conjunctures have shaped a habitus that maximizes economic and legal security for families and individuals, especially women. ${ }^{8}$ In the first section, I examine the rupture during the Great Depression and its consequences in terms of the arrest of immigration flows and discrimination towards the Chinese. In the second, I consider the familial adjustments in the 1960 s that resulted from the economic boom, the facilitation of naturalization and assimilation, and tightened French metropolitan control over the colony. This was a moment of temporary adequacy between the first- and secondgeneration Chinese's aspirations and political context soon challenged by the rise of the Tahitian pro-independence movement and the reopening and mounting hegemony of China. Finally, I indicate how these practices of adjustment have shaped flexible management of family members, visible in a set of practices that continue even though the descendants of migrants are now all French citizens. These practices are explained by the political and economic crisis in French Polynesia and by the internalization of the possibility of politico-economic reversals as experienced in family histories.

\section{Relocating sons and 'not recognizing' daughters: from 'laissez-faire' to discrimination in the 1930s}

Following a widespread pattern in the history of Chinese migration in the second half of the nineteenth century, the introduction of some 400 contract labourers or 'coolies' in the mid-1860s triggered a larger wave of migration, based on recruitment by the Chinese themselves. Immigration to the colony intensified with the 1911 Revolution in China and lasted until the mid-1930s. During that period, the colonial administration allowed Chinese immigrants to enter the territory freely (rather than on contract) because it considered them as tools for developing the colony without governmental intervention. The Chinese brought labour and capital into a colony in which the native population had sharply decreased during the nineteenth century and attempts at developing a plantation economy had failed (Panoff 1991). They developed a network of shops based on a complex system of credit and patron-client relationships: small shopkeepers in the islands exchanged goods for agricultural produce (copra, nacre, and vanilla), which they treated, packaged, and sent to their patrons in the urban centres of Papeete and Uturoa, who in turn provided their clients with imported goods (Moench 1963). If the Chinese merchants first sold copra or vanilla to the Europeans, they soon had the means to launch their own import-export firms that had ties with other Chinese firms across the Pacific, in Hong Kong and San Francisco.

From the 1890s, the colonial elite's representatives put pressure on the colonial administration and tried to restrict or stop Chinese immigration and slow the economic progress of the Chinese. A few also demanded that the Chinese be assimilated and criticized the policy of their indirect rule. The immigrants belonged to associations (congregations) that ran their own schools and whose heads were the representatives of the community and interlocutors of the governor. The associations were also political parties divided along cleavages that mapped onto China's own political state of affairs. The colonial administration rejected the elite's demands and pursued a laissez-faire 
policy towards Chinese immigration, for economic but also political reasons. The colonial administration viewed the Chinese as a means of balancing between the native Tahitians, who were not willing to work on colonial plantations, and the elite of Euro-American origin, who increasingly formed an economic oligopoly and expressed demands for a political role beyond the consultative role to which they were confined. As one governor explicitly stated in 1926, 'The Chinese are a necessary evil in the present state of this country ... they serve as a counterweight to the claims of the Whites who cannot forgive them for taking their place in the exploitation of the Natives'. ${ }^{9}$

The migrants' goal was to accumulate sufficient economic capital to return home and reconvert it into social and symbolic capital. As 'sojourners' (Wang 2000), they kept close connections with their villages of origin, which were all located in Southern China's Guangdong province, and often travelled back and forth until the 1930s. During that period, flexible kinship consisted mainly of spatial localization of family members linked to patterns of immigration and orientated towards the continuation of the family line in China. Several brothers migrated to the same destination, one after the other. It was usually the eldest who opened a shop and then sponsored his younger brothers, who, each in turn, worked in the enterprise until they had repaid their tickets and could open their own shops. It was also usually the eldest who was the first to return to the home village in China.

There was a high rate of intermarriage between Chinese men and Tahitian women in the first generation, and with part-Tahitian women in the succeeding generations. Only the big merchants in the urban centres had the means to bring over a Chinese wife. Many who settled in the rural districts and islands spent their entire lives with Polynesian women. From the 1920 s to the mid-1930s, first-generation immigrants often sent back one or two of their eldest sons to China, around the age of 8 or 9 , to be raised by the immigrants' parents, elder uncles, and/or legitimate wives in China. This was intended not just to prepare the father's own return, but also to provide a proper Chinese education, especially for those born from a Tahitian mother.

Another option was to send sons to Chinese schools in Tahiti, but these schools provided only primary education. Moreover, in the case of sons born to Tahitian women, the aim was to ensure not only complete 'sinicization', but also, as important, their acceptance within the patrilineage. The villages of origin were often single-lineage villages, or villages composed of at most two or three lineages, and the schools were established (through overseas funding) by these lineages. Sending 'mixed' sons to the village of origin to be socialized within the lineage was a means of ensuring legitimacy (Skinner 1957: 246-7; Watson 1975: 147). Although my research uncovered a few cases in which daughters were sent back as well, the dominant pattern consisted in sending back sons.

The economic downturn of 1929-30 led to a change in policy towards Chinese migrants at the same time as it modified, by force of circumstances, their behaviour in terms of land acquisition. Until then, buying additional land in their home village was one of the migrants' aims, rather than acquiring land in the host country. In 1927, the number of Chinese landowners was only an estimated 250. The global market crash in the early 1930 s had followed a boom (in vanilla especially) in the 1920 during which Tahitian clients had accumulated huge debts towards Chinese shopkeepers. This led to several bankruptcies of large exporting firms, owing to the pyramidal system of credit; this, in turn, led Chinese shopkeepers to reclaim debts to their clients. Insolvent clients therefore started repaying their debts with land. The equilibrium the colonial 
administration had so far preserved threatened to collapse. It is thus no coincidence that, in the following years, it took two measures aimed at restricting the economic power of the Chinese. In 1931, a decree imposed a duty on all people 'of Chinese race exercising a commerce, industry, or profession' to pay an additional tax on a basic trading licence. This was followed in 1932 by a degree that subjected any transfer of real estate to administrative authorization - in principle without any distinction as to nationality or status, but colonial correspondence makes it clear that this regulation targeted the Chinese. In the following years, the administration also took several measures to halt Chinese immigration.

These measures led to a slowdown in transnational flow and mobility, but they also generated a discrepancy with the changing orientations of the migrants. Because of the Japanese invasion of China in 1937, and later the Chinese civil war and the loss of their savings in the economic crisis, Chinese migrants started conceiving of their presence in Tahiti less as a temporary sojourn than as an undetermined period of residence without a clear plan for return to their home villages.

Not only did they stop sending their children back to the homeland; they started devising strategies that would allow their children to escape discriminatory taxes and prohibition on land acquisition. From the 1930s onwards, and well into the 1950s, the Chinese migrants frequently used fraudulent means - such as false names - to operate businesses and buy land. Along with these subterfuges, they registered shops or land in the name of daughters, and more frequently wives, who held French citizenship. Whether the mother was Tahitian or Chinese, couples were not legally married according to French civil law, and therefore the only way to prove filiation was by the legal recognition of one's children. In almost every family history I collected, I found one or several second-generation female children (and even all in some families) whose parents had not legally recognized them at birth. They thus gained French citizenship. When the father was Chinese and the mother Tahitian, only the mother recognized these daughters; in families with a Chinese father and mother, parents asked friends or neighbours to recognize these daughters in their place, or with the note 'father and mother unknown'.

This practice seems to be doubly consistent with women's place in the Chinese family as conceived at the time of migration. Daughters were expected to leave the family line by marriage and excluded from inheritance of the family estate, which was to be divided equally among sons. They did, however, receive a dowry, and remained owners of it after marriage. Women were actually the only individual property holders (Cohen 1968 : 167-9); men owned no property individually, since it was always that of the family. At the time of family division of property, the properties of wives were set apart. Marjorie Wolf (1972: 166) has even suggested that what she called the 'uterine family', a de facto social unity consisting of a mother and her children, catalysed this tendency to fission, against the ideal of the patrilineage and the joint or extended family (and I have argued elsewhere [Trémon 2010] that this was indeed the case in French Polynesia).

The non-recognition of a daughter so as to allow her to hold French citizenship acted as the equivalent of a dowry - in legal, rather than economic, capital. Indeed, daughters born to Chinese families but holding French citizenship were in high demand. This explains why such a practice was more common among the poor majority than in wealthy families, whose fathers could endow their daughters in cash. In most situations, wives were used as 'straw-women' to buy land or register shops. The history of the Hong $^{10}$ family is interesting in this regard (see Fig. 1 on p. 13). 
This family arrived among the last wave of migrants, in the mid-1930s. Two of the eight children were daughters; the eldest was married away as the family transited through Malaysia. The father earned a meagre salary as a teacher at the Kuomintang school. The two eldest sons started working when they were 12 years old as odd-job boys in a shop owned by Americans. It was they who initially provided the family's livelihood. Their work allowed the family to pay for the education of their younger brothers in a French Catholic school after they had attended a Chinese school. (All urban Chinese families paid for these extra years as soon as they could, because mastery of the French language was considered indispensable for business and dealings with the administration.) The fourth son and last daughter worked for the third son, who had managed to open a shop with the help of the elder brother's income.

At that time, the family economy was inclusive; it had not yet been divided. The income of the third son's shop and the salaries of the two eldest were combined in the family budget; meals were taken together; and each son received a small amount of pocket money for personal expenses. Fabien Hong, the son of the fifth son, explained to me that it was this third brother (and not the eldest) who became the official family head after their father died, but that he had already been the 'chief' before his father's death

because he [the third brother, Fabien's uncle] spoke French better than the two eldest brothers. He went to the Catholic school a bit; the [elder brothers] went to the Chinese school, period. And also because his wife, Amélie, was the only Frenchwoman in the family at that time. And this is how we got the shop licence from the trade registry.

The family business thus grew around him: 'Everyone worked in the shop Amélie [named after the wife] except the two eldest'.

The history of this particular family shows how the general habit of not recognizing girls among the Chinese in Tahiti was part of a larger family strategy, whereby the entire familial workforce was used to achieve economic success by 'investing' in one asset - one particular family member. It also reveals how the family's authority structure changed. The third son took over the role of 'chief' as dispatcher of family income and manager of the company employing his brothers and sister because the trade licence was drawn up in the name of his wife, an unrecognized daughter of Chinese immigrants and thus a French citizen.

\section{Family fragmentation, the nuclear boom, and access to French citizenship in the 1960s}

Although some among the first generation stood out by building fortunes early in the twentieth century, the second and third generations have benefited most from the economic opportunities that multiplied in the 1960s. The opening of airlines promoted tourism, and the transfer of France's nuclear testing from decolonizing Algeria to French Polynesia in 1962 accompanied massive investments and the growth in consumption of imported goods owing to the increased presence of French soldiers and civil servants, and the generalization of salaried employment. While the first generation of Chinese immigrants included many shopkeepers, but also farmers, their children turned towards commerce, services, and especially imports. It is also during this period that access to French citizenship was first facilitated, and then became automatic. There is, therefore, an overall convergence between the descendants of migrants' aims and orientations, and the field of political and economic possibilities. I emphasize how seizing these 
opportunities has both presupposed and accelerated family fragmentation, and the generalization of conjugal families.

While most of the second generation, particularly girls, only had a Chinese primary education, some could attend private French schools after Chinese schools, and a very small minority were able to study at high schools and universities abroad. From the early 1940s onwards, the sons of the wealthiest Chinese tradesmen started to leave to study in mainland France or in America, rather than in China. These were often the eldest sons, destined to seek new business opportunities. In less wealthy families, only the youngest siblings could go abroad, owing to the elders' work. Thus, in the Hong family, the work of the four elder sons and the daughter paid for the last two sons' studies. They went to France to earn a baccalauréat (high school) and higher education diplomas. Around the mid-1950s, when the two youngest sons returned from France after completing their studies, the father divided the family estate. Fabien Hong explained:

\footnotetext{
The company was overcrowded, and so my grandfather decided to scatter the family. So in family council it was decided that my father, who had learned farming, would go to Brazil, so there, Brazil. My uncle [the last son] was told, 'You go back to France'. And then the family actually split, and the estate was shared. Each one of them left with his share to set up his own business.
}

According to Myron Cohen's observations in rural Taiwan (1970), fenjia, family division, begins with the initial scattering of family members decided by the elders. It occurs in families who own little land and is driven by the diversification of family economics and the development of non-agricultural trades. Here we see that the Hongs' international dispersion coincided with family division and reflected different types and degrees of investments in each sibling. Such a strategy is a typical response to 'the petty accumulation trap' (Nonini 2003; 2005) that Chinese small-scale capitalists face as a result of demographic reproduction and the pressure exerted by the population increase on businesses like the Hongs' owing to the principle of equipartibility among sons. (The petty accumulation trap does not apply to the larger-scale businesses of wealthier Chinese entrepreneurs.) One response is then to spatially disperse fathers and grown children by extending the businesses' operations (Nonini 2003: 85). The most common response, however, is to opt out 'laterally' and convert economic capital into other forms of capital by pressing excess younger members to seek university degrees, very often abroad (Nonini 2005: 173). ${ }^{11}$ The Hong family resorted to both responses at once. The division tried to exploit the workforce as much as possible; an inclusive economic unit would have left them 'overpopulated' and underemployed. The dispersion was also meant to enable each son to exploit his capacities, especially the two youngest, who held higher degrees and had specific skills. And indeed, both siblings did very well: one, after working as an agronomist in Guyana, came back to Tahiti, where he set up a flourishing import business in agricultural tools and machinery; the other came back to set up a business that imported cars from a major French manufacturer. He eventually became the exclusive supplier of the French army in Tahiti.

The Hongs' case illustrates how the family development cycle accelerated in this context. This resulted from the decisions that were taken in the 1950s and 1960s, once the second generation reached adult age, to proceed to the division of family property in order to maximize opportunities. The economic boom in the early $1960 \mathrm{~s}$ happened when many second-generation Chinese had become adults or reached maturity and had to take care of their own children's future. This tendency towards fragmentation went against the ideal of the extended family and joint complex of 
companies, which only some successful families in Tahiti were able to reach. Several sons of some of the wealthiest families, who had settled in the United States after their studies, started in business by creating US-based import-export or tourism companies in association with their families in Polynesia. But most families had already divided by the time the economic boom would have made such arrangements profitable.

Paradoxically, strategies of geographic dispersion across borders, like that of the Hongs, were soon followed by returns to Tahiti. These returns not only sought profit from the phenomenal economic boom of the 1960s; they also responded to the less stringent naturalization criteria of the period. Indeed, this issue, which had until then not attracted much interest, became urgent when France established diplomatic ties with the People's Republic of China (PRC) in 1964. The French Polynesian Chinese had been under the legal jurisdiction of the Republic of China (ROC) since 1943, and remained so after its exile on Taiwan in 1949. France's recognition of the PRC meant that the consul of the ROC, who represented them, was to be replaced by a consul of the PRC. The nuclear testing programme made the prospect of a Chinese Communist presence in this strategic French overseas territory unacceptable. Therefore, the Chinese schools were closed in 1964, and the consulate followed in 1965.

Stories of hardships faced by those who had returned to China at the end of the war, the hostility towards overseas Chinese 'capitalists' (Fitzgerald 1972: 55), and the closing of China's doors after 1949 changed how the Chinese perceived their status in French Polynesia. Beginning as sojourners, they had become permanent residents. This rooting was stronger among second-generation members born in the colony and notably among those of the elite who went to study in France. When sons of the wealthiest Chinese families came back from France in the mid-1950s, they took part, with several successful young businessmen, in the foundation of an association campaigning for mass naturalization, the UDPF (Union pour le Devenir de la Polynésie Française).

The granting of French citizenship was all the more desirable for many Chinese because it offered political and civil rights and removed the discriminatory taxes still levied on foreigners. (Although the ROC Consul had pressured France into suppressing its additional tax on commercial licences in 1948, the Chinese still had to pay a residence tax and a tax on the delivery and renewal of the 'identity card for alien traders' created in 1940.) Moreover, many Chinese experienced the fact of being citizens of a Republic in exile, combined with the feeling of being rejected by the PRC, as a situation of statelessness. The Chinese therefore perceived naturalization as the resolution of a legal limbo and a normalization of their status, putting an end to the discrimination they faced. Furthermore, the 1960 s was a decade of mounting opposition by the autonomists to the pro-France de Gaullian party that formed the majority in the French Polynesian territorial assembly. The members of the UDPF who campaigned for naturalization argued that it would turn them into loyal pro-French voters. As the autonomists openly took anti-Chinese stances, the Chinese saw the control of the territory by France as a warrant that would allow their continued presence. The law of 1973 extended jus soli to France's overseas territories and a decree immediately followed that granted French citizenship to all those born in the territory.

The fragmentation into conjugal families was accelerated owing not only to strategies of economic and cultural capital accumulation, but also to naturalization - the 
acquisition of legal capital. Naturalization was an individual act, and the 'Frenchification' of Chinese names was part of the procedure. It consisted in reworking the names according to French phonetics or even changing them to something altogether different. This led to a great variety of surnames. Thus the name Lan could become Lanne, or, as rewritten by some zealous clerks, even the very common Dupont. Some adopted the first name of their wife, after which they had named their shop; such as the third Hong son, who took the patronym Amélie. For those whom the 1973 decree had naturalized, this phonetic adaptation was optional, but as the authorities proceeded case by case, siblings and cousins bearing the same original Chinese surname often obtained very dissimilar French surnames. This 'dispersal' of surnames often came up during interviews as an example of individualization, in contrast to an earlier golden period where families were more unified and solidary. Between the 1930 s and 1950s, joint and extended families prevailed, in which some members' work allowed others to diversify their business. By contrast, many interviewees viewed the 1960 s as a time of 'every man for himself'. While perceived as radical break with the past, the Hongs' case demonstrates how this fragmentation was actually the very result of the strategies followed by the families.

This is most clearly shown by the ways in which the practice of using women as nominal owners led to unwanted consequences. At the time of the division of the family estate, dissent appeared among brothers, on the one hand, and between brothers and sisters, on the other. First, the son married to a French wife could often slight his brothers at the time of the split. The Hong brothers felt that the monetary compensation they had received at the time of division, from which they had to start from scratch, was less than the part received by the third brother who kept the shop. Second, once all had become French citizens, daughters could claim a share of the estate registered in their name, even though their parents had not intended to give them anything at all. Some even took action in court, in spite of this being seen as a disreputable move in the community. ${ }^{12}$ Women thus challenged Chinese gender hierarchy in the name of French law, which mandates equal inheritance between all children. Among the third and fourth generations, sons and daughters inherit equally from their parents, in conformance to the legal dispositions of the French Civil Code. This further generalized the conjugal family.

In the meantime, the regime change in China led to the split of the family estate that was once bilocal. Owing to confiscations of land and property accumulated by successful overseas Chinese that took place as soon as the Communist Party took power, and to the collectivization of land that occurred in the early 1950s, the family estate in the villages of origin generally shrank to the house inhabited by returned members of the family or held in trust by fellow villagers. This loss of property led to a re-centring of the family estate in French Polynesia that favoured those who had not gone back - the younger siblings. Many of those who had gone to China managed to flee to Hong Kong at the end of the 1950 os and early 1960 s as part of the massive wave known as Dataogang (Chen 2011). Many others migrated again from Hong Kong to other destinations in the Americas and Europe. Those who came back to Tahiti found themselves dependent on their younger brothers, or on their father's younger brothers, contradicting the hierarchical logic that had led to their return to China in the 1930 . Moreover, the Chinese education they had received was of no use at a time when success in business and access to French citizenship were highly dependent on French cultural capital. 


\section{Continued flexible kinship}

In the space of two decades, the 1960s and 1970s, French Polynesia saw a radical transition from a dual economy based largely on subsistence and partly on exports, to an economy based on the nuclear rent. This made the post-nuclear reconversion that started in the 1990s extremely difficult. The French Polynesian economy is now still extremely dependent on financial aid from France. Its debt has become huge, and this makes its trajectory, in spite of its specific history as a French overseas territory, quite similar to that of many formerly colonized developing countries. The French authorities have attempted to boost investments through a policy of generalized tax exemptions. In the absence of income, wealth, and inheritance taxes, inequalities are particularly pronounced, and 27.6 per cent of the population lives below the poverty line (Herrera \& Merceron 2010: 7). On the island of Tahiti, the contrast in standards of living between the well-to-do and the poor is striking. The former live in villas with lagoon views on the heights, the latter, increasingly, in housing projects and slums. These inequalities clearly intersect with ethnic divisions between the Tahitian, Chinese, and French. Following Fredrik Barth's (1988) logic of ethnic boundary maintenance, the Chinese are overrepresented in private business, even though many have entered the public sector as school teachers or civil servants. The ethnicization of identities in Tahiti has also been fostered by the competition between the rising independence party and the autonomist party, and can be seen as an effect of the de-hegemonization of the Western-dominated world system in the 1970 (Friedman 1994; 2004: 82). Furthermore, and as part of this same global process of 'hegemonic transition', the promotion of multi-ethnicity through the branding of the 'Chinese community' has been used to establish diplomatic relations with the PRC. These efforts have met those of the PRC, which has, since the early 1980s, reconnected with its diaspora's communities in French Polynesia and elsewhere, using an enlarged definition of 'Chineseness' (Dirlik 2004; Nyíri 2002).

In this unstable, uncertain political and economic context, practices of 'flexible kinship' take the form of a search for the diversification and securitization of economic assets simultaneously with an exploitation of the opportunities that French Polynesian residence continues to offer. These practices by descendants of Chinese migrants pertain to a diasporic rather than a migratory transnationalism, in the sense that they are orientated less to the country of origin than to other destinations. Although the reopening of China from 1979 encouraged those of the first generation who were still alive, and the second generation (especially those sent back during childhood), to visit their villages of origin, on the whole there was a distancing, if not a breakup, of family ties (as Hoe [2005] argues). Furthermore, while many entrepreneurs make frequent trips to China to supply their import businesses, family ties rarely frame business relations (as shown by Smart and Smart [1998]). One exception is the case of two brothers who have used lineage-village ties to act as intermediaries with a Chinese state agency in the recruitment of workers for pearl farms in the Tuamotu islands.

A set of more widespread transnational practices is the internationalization of economic, legal, and cultural capital by means of exporting savings, accumulating citizenships, and getting degrees abroad. We will see, however, through the Lin family, that these are not necessarily systematic and can conflict with localized identities.

The Lins (see Fig. 1) are third-generation descendants of Chinese immigrants, born in the 1950s. Jean-Pierre grew up on the island next to Tahiti, Moorea, where he inherited half of his father's business (a grocery-bakery). Eliane grew up on Tahiti in the urban 


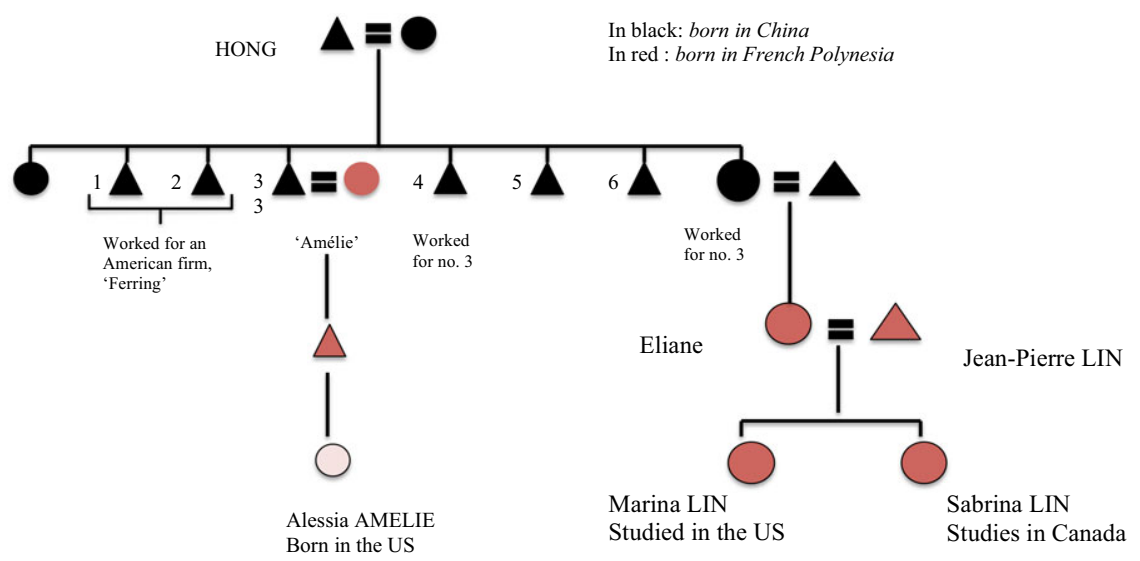

Figure 1. The Hong and Lin families.

Chinese community, where she went to the Chinese school. After briefly studying in France, she came back and found employment in the enterprise of her maternal uncle, the last son of the Hong family (she is the only daughter of the Hongs' younger sister). After her marriage, she moved to Moorea to work together with Jean-Pierre in the grocery shop. When their first daughter, Marina, reached legal majority, they registered their enterprise as a limited liability company under her name (she is officially the manager) and themselves as her employees. This brought two advantages: the first is that it evaded corporate tax and led them to be taxed at a very low level; $;^{13}$ the second is that it allowed them to contribute to a retirement pension scheme for employees that was more favourable than the one for enterprise heads. This legal arrangement, which profits from the low tax regime specific to French Polynesia, is extremely widespread among Chinese shopkeepers. It relies, evidently, on relations of trust and authority between parents and their children. 'It works if children do not rebel', as Marina told me. We find here a continuation of flexible kinship practices, although this particular type is not strictly transnational.

Marina herself is employed, and so is her husband William; they work for the local airline company and a bank. They will not take over William's parents' shop, nor Marina's parents'. They are not willing to wake up at 4 a.m. and work all week without a day of rest, as their parents did, 'and anyway, you cannot make as much money out of a shop nowadays', said Marina. However, she recognizes that, as employees, they will never be able 'to accumulate as much' as their parents did. Marina's and William's parents belong to the generation that was born Chinese and became French in 1973 and has largely benefited from the economic growth that continued until the 1990s. From the moment they got a French passport, the members of this generation have been able to travel easily internationally. This generation has strongly resorted to 'birth tourism', a practice consisting in travelling (with a tourist visa) to a jus soli country for the purpose of giving birth, thereby granting their child birthright citizenship or enhancing his or her future chances of getting citizenship. In one case a couple gave birth to four children, all in different countries (Australia, New Zealand, Canada, and the United States). Accumulating a wide range of citizenships within a family increases the legal capital of the family and of each member. In the same vein, third-generation parents generally influenced their children's choices of location for studying abroad, 
encouraging each to select a different destination. As one informant put it, the idea is that 'one should not put all of one's eggs in one basket'. Birth tourism is part of this same rationale, since children born in a country will have better chances of admission and are more likely to choose schools there.

Unlike her rich cousin Alessia, the granddaughter of the third Hong son, an American citizen by birth who chose to follow her boyfriend to France (to her mother's dismay), Marina herself was born in Tahiti but opted for the United States. Her parents did not have the means to practise birth tourism, but her mother did push her in that direction. (Marina thinks her mother transferred to her the aspirations held for herself by her grandfather, who had been an influential Kuomintang member and therefore strongly orientated to the United States and opposed to Communist China.) Marina believes she would have chosen France if the decision had been her own, but her mother argued that an American degree and the English language were a backup. America is 'a plan B', she said, 'because we already have the French citizenship, which is a good one, it is part of the European Union'. In other words, what is at stake is a diversification of different forms of capital, and, hence, options for the future.

Since Marina's return in 2002, French Polynesia has gone through a sharp economic crisis because of the impact of the 9/11 attacks, and now the world economic crisis, on tourism. There has also been a deep political crisis since the accession to power, for the first time in 2005, of the independence party. This has increased the tendency among Tahitian Chinese to place their savings and assets abroad, in bank deposits and real estate.

In 2014, Marina's mother Eliane bought two apartments in Montreal's Côte des Neiges neighbourhood. She chose Montreal because it is the place where her second daughter, Marina's sister Sabrina, has been studying biology for several years, more recently as a Ph.D. candidate. Marina's mother gave the information about this opportunity to several people, all very close female friends, who purchased apartments in the same building. Eliane's parents did not own a shop and placed nothing in her name; however, she is strongly mindful of how her mother, the last Hong sister, was the 'slave' of her brothers all her life and received nothing at the time of family division. Eliane told her daughters that she had sworn to herself to give her own daughters everything they needed and never act as the 'elders' did in the old times; she calls this 'acting as a civilized Chinese'. The two apartments in Montreal are in the names of Marina and Sandra.

Eliane and Jean-Pierre also own a house on Moorea, where they live, and one on Tahiti, in which Marina resides. They used to own an apartment in France and one in Australia, but sold both recently because of declining prices and in order to invest in Montreal. Eliane is also the part-owner, with her father, of a house in New Zealand, and she and her husband own two pieces of land in the Tuamotu islands, which Jean-Pierre bought for a very low price. Buying real estate abroad was Eliane's decision, which Jean-Pierre does not support. Recently, his decision to buy an additional piece of land on the island of Moorea led to a huge dispute between them, to the point where Marina thought they were about to divorce. What structures their debate on whether to invest locally or abroad is the prospect of the country gaining independence, ${ }^{14}$ but also, in the shorter term, their retirement plans. If the country were to gain independence, Eliane proclaims she would leave at once, while Jean-Pierre swears he will defend his property with a rifle.

Jean-Pierre grew up on Moorea, two of his sisters are married to Tahitian men, and he likes practising hobbies associated with islander lifestyle, such as fishing. ${ }^{15}$ He sees 
himself spending his old age fishing in the Tuamotu islands. His father had bought an apartment in China in preparation for his own retirement, but died before he left, and Jean-Pierre told me, 'Honestly, I don't give a damn about China'. Neither does Marina's mother, but she envisions herself spending half of the year in Montreal upon retirement. Marina is rather inclined to her mother's way of thinking. She could see herself living in Canada, and she and her mother reason that now that Sabrina has Canadian citizenship, she could sponsor them in case they decided to make the move. ${ }^{16}$

While the difference between Jean-Pierre and Eliane is clearly linked to their socialization in different settings, the purchase of the Montreal apartment together with several women, and her own family history, also suggest that transnational flexible kinship practices may be continued by women more than by men because of the central role they play in family arrangements and the way this has enhanced their economic roles.

\section{Conclusion}

In this article, I have shown the discrepant temporalities between, on the one hand, immigration and citizenship policies, which fluctuate along with global economic conjunctures and reconfigurations of hegemony in the world-system, and, on the other, the orientations of migrants and their descendants. These successive changes have animated the practices of flexible kinship. Flexible kinship depends on the organization of the kin unit - the dynamics of its development cycle - and on its internal relations the hierarchy based on birth, generation, and gender. It involves strategies of spatial and legal localization that consist in the crossing of national borders by some of the families' members with the aim of evading constraints and benefiting from opportunities. Of course, kinship may always be flexible. I have argued that the phenomena described are an accentuation of processes already present within the very logics of family dynamics itself. Although this may make the notion seem redundant, flexible kinship draws attention to the specific uses that are made of kinship in the context of migration and diaspora: the adjustment to cultural, political, and legal borders that lead to changes in family forms and in the relations between kin. In this sense, the concept also brings to light the added value of a transnational perspective, which places the emphasis on the dynamics of border-crossing.

In addition, flexible kinship invites looking at kinship as both a resource for action and the result of this action. Kinship is in itself a resource for action, since its variable uses make it possible to acquire different forms of capital in other spheres (Bourdieu 1990 [1980]). At the same time, it is also the result of this action, insofar as the form the family takes, and the nature of the relation between its members, are the product of these adjustments. Peggy Levitt and Nina Glick Schiller have emphasized that 'using a transnational lens reveals the changing nature of the family as a socioeconomic strategic unit and how family ties are worked and reworked over time and space' (2004: 1017). If the 'cultural logics' of the Chinese family have framed the transnational practices of flexible kinship, the latter have also modified these logics and affected the relations between kin. On the one hand, the Confucian hierarchy that underlay the relations between kin has been bent, adjusted to reach the desired benefits. Yet, on the other hand, these adjustments have sometimes led to unintended consequences for the families' organization and internal relations. First, they have led to an accelerated fragmentation of families into conjugal units and fostered the severing of ties with kin that remained in or returned to their villages of origin. Second, hierarchical relations 
have to a great extent been weakened and they have largely disappeared in the case of gender, as I have shown through the greater importance given to the 'uterine' family and the equalization of status between men and women.

Furthermore, flexible kinship involves a processual approach to kinship. In this regard, a multi-generational perspective shows how families adjust to and benefit from differences, in space and time, in cultural, political, economic, and legal regimes and (more or less favourable) conjunctures. The differentiated strategies and investments in family members were intended to profit the family as a collective unit. These flexible arrangements, requiring members to make sacrifices by investing in some individuals for the benefit of all, stimulated division, accelerating the family development cycle.

Finally, discrepancies between successive changes, reversals in policies over the longue durée of family history, and the history of adjustments to them have produced a habitus, or a set of dispositions, that are orientated towards the maximization of economic and legal security, possibly even more among women. It is visible in the constant concern for adaptation and anticipation of further reversals that continue today among descendants of migrants who hold French citizenship.

\section{NOTES}

This article was presented in November 2015 at the American Anthropological Association annual meetings in Denver. I am grateful to the panel organizers, Winnie Lem and Pauline Gardiner Barber, and the discussant, Nina Glick Schiller, for their warm encouragement. I also owe thanks to Mark Goodale as well as to the JRAI's reviewers and then Editor, Matei Candea, for their careful reading and supportive suggestions.

${ }^{1}$ The material presented here is largely drawn from my doctoral research (2000-5) and two follow-up research visits in 2008 and 2013. It also includes a few elements from the new project I have been working on since 2011 in one of the villages of origin of Tahitian Chinese, in Shenzhen, China. In Tahiti, I carried out participant observation, collected archival material, and conducted over a hundred interviews mainly with second- and third-generation descendants of Chinese immigrants. These open-ended interviews often took the form of personal and family histories.

${ }^{2}$ I refer to kinship here in the larger sense that the term has in French, where it embraces what the English language refers to as kinship but also the notion of alliance (relatedness) (cf. Godelier 2011 [2004]).

3 There are also lineage associations, which I do not address here as they are beyond the scope of this article.

4 This is obvious in regimes based on jus sanguinis (right of blood) but also in those based on jus soli (right of the soil or birthright citizenship) as shown by de la Pradelle (1995). The vast majority of nationals receive French citizenship at birth, as a function of filiation.

${ }^{5} \mathrm{EFO}$ was the name given to the islands annexed by France in 1881 . The colony was transformed into an overseas territory in 1946 and renamed 'French Polynesia' in 1957.

${ }^{6}$ Between 1904 (the year when a new count started) and 1948, 5,404 Chinese were registered; 2,927 left. Therefore, the net gain is 2,477. Not all were immigrants; some were born in the colony during that period.

7 Colonies were ruled administratively by simple decrees, and not legislatively. In the decrees applicable to the colony, single and double jus soli contained in the laws of 1889, 1927, and the 1945 Code were absent.

${ }^{8}$ This is thus not a Confucian habitus, but a disposition towards flexible adaptation shaped by a history of adjusting to changes.

${ }^{9}$ Report from the Governor to the Ministry of Colonies, 11/05/1926, file no. M19, 125, Centre d'Archives de la France d'Outre-mer.

${ }^{10}$ All patronyms and first names cited in this text are fictitious. They do, however, reflect the original names' Chinese, Tahitian, or French consonance.

${ }^{11}$ In the case of the Malaysian Chinese petty capitalists studied by Nonini, emigration to seek education abroad is a result of the restrictions placed by the Malaysian state on the access by young Chinese to the universities. In the case of French Polynesia in that period, this was simply because there were no institutions of higher education locally (and up to the late 1980s).

${ }^{12}$ There might be a sense of revenge in the ways some women filed lawsuits against their families when brothers (in many cases) denied them the right to a share at the moment of family division. It is, however, the non-recognition of their work, rather than the legal act of non-recognition, that fuels a feeling of frustration and a desire for reparation. I have never heard anyone complain about this legal practice nor express any 
suffering because of it. This might be due to the general repression of feelings and emotions that is quite obvious within the community (and about which some members of the younger generations complain). However, those among my interviewees who did express suffering had been circulated as adopted children, rather than subjected to fictitious arrangements with the law (Trémon 2007).

${ }^{13}$ Corporate tax varies from 35 to 45 per cent of profit. In France, enterprise heads can opt for a single proprietorship, which is normally subjected to income tax. As there is no income tax in French Polynesia, these types of enterprises are taxed on transactions, which amounts to only 5 per cent of the sales revenue.

14 In 2011, the Territory's Assembly adopted a resolution seeking self-determination within United Nations processes. In May 2013, the United Nations General Assembly voted to place French Polynesia back on the United Nations list of territories that should be decolonized.

${ }^{15}$ For a discussion of different milieus of socialization and contrasts in lifestyles between rural districts and islands and the Chinese in Papeete, and corresponding 'localization' and 'cosmopolitanization' of identities, see Trémon (2009).

${ }^{16}$ There is also, of course, an affective dimension to the choice of location for investment and, possibly, future residence, in accordance with the place where Sabrina lives. Eliane's speech is, however, mostly framed in rational-strategic rather than affective terms - a source of resentment for Marina.

\section{REFERENCES}

Barth, F. 1988. Ethnic groups and boundaries: the social organization of culture difference. Prospect Heights, Ill.: Waveland Press.

Bourdieu, P. 1990 [1980]. The social uses of kinship. In The logic of practice (trans. R. Nice), 162-99. Cambridge: Polity.

BrandtstäDter, S. \& G.D. Santos (eds) 2009. Chinese kinship: contemporary anthropological perspectives. Abingdon, Oxon: Routledge.

Bruguière, A. 2002. Les sciences sociales et la notion de solidarité familiale. In Les solidarités familiales en question (eds) D. Debordeaux \& P. Strobel, 19-40. Paris: Maison des Sciences de l'homme.

Bryceson, D.F. \& U. Vuorela 2002. The transnational family: new European frontiers and global networks. Oxford: Berg.

Carsten, J. 2004. After kinship. Cambridge: University Press. 2013. What kinship does - and how: comment on SAHLINS, Marshall. 2013. What kinship is - and is not. Chicago: University of Chicago Press. Hau: Journal of Ethnographic Theory 3: 2, 245-51.

Chamberlain, M. \& S. Leydesdorff 2004. Transnational families: memories and narratives. Global Networks 4, 227-41.

Chen, B. 2011. Dataogang 大逃港. Xianggang: Xianggang Zhonghe chuban youxiang gongsi.

Cohen, M. 1968. A case study of Chinese family economy and development. Journal of Asian and African Studies 3: 3-4, 161-80.

1970. Development process in the Chinese domestic group. In Family and kinship in Chinese society (ed.) M. Freeman, 31-6. Stanford: University Press. 1976. House united, house divided. New York: Columbia University Press.

De Hart, B., W.M. van Rossum \& I. Sportel (eds) 2013. Law in the everyday life of transnational families. Oñati Socio-Legal Series 3: 6 (Special Issue).

De la Pradelle, G. 1995. La distinction entre droit public et droit privé en matière de nationalité. In C.U.R.A.P.P.: public/privé. Paris: Presses Universitaires de France.

DirLIK, A. 2004. It is not where you are from, it is where you are at: place-based alternatives to diaspora discourses. In Worlds on the move (eds) J. Friedman \& S. Randeria, 141-66. London: I.B. Tauris.

Ebrey, P. 200o. Preface. In The sage and the second sex (ed.) C. Li, i-xiii. Chicago: Open Court.

Fitzgerald, S. 1972. China and the overseas Chinese: a study of Peking's changing policy 1949-1970. Cambridge: University Press.

Friedman, J. 1994. Cultural identity and global process. London: Sage.

2004. Globalization, transnationalization, and migration. In Worlds on the move: globalization, migration and cultural security (eds) J. Friedman \& S. Randeria, 63-90. London: I.B. Tauris.

Gallin, B. 1966. Hsin Hsing, Taiwan: a Chinese village in change. Berkeley: University of California Press.

Glick SChiller, N., L. BASCH \& C. BlanC-SzAnton 1992. Towards a transnational perspective on migration: race, ethnicity, and nationalism reconsidered. New York: New York Academy of Sciences.

Godelier, M. 2011 [2004]. Metamorphoses of kinship (trans. N. Scott). London: Verso.

Goody, J. 1958. The developmental cycle in domestic groups. Cambridge: University Press. 1983. The development of the family and marriage in Europe. Cambridge: University Press. 
Greenhalgh, S. 1994. De-orientalizing the Chinese family firm. American Ethnologist 21, 746-75.

Herrera, J. \& S. Merceron 2010. Les approches de la pauvreté en Polynésie française (Working Paper Series no 103). Paris: Agence française de développement.

HoE, Y.C. 2005. Weakening ties with the ancestral homeland in China: the case studies of contemporary Singapore and Malaysian Chinese. Modern Asian Studies 39, 559-97.

HuAnG, S., B.S. YeOH \& T. LAm 2008. Asian transnational families in transition: the liminality of simultaneity. International Migration 46: 4, 3-13.

Kearney, M. \& C. Nagengast 1989. Anthropological perspectives on transnational communities in rural California (Working Paper No. 3), California Institute for Rural Studies. Working Group on Farm Labor and Rural Poverty, 1-42.

Kuper, A. 2008. Changing the subject - about cousin marriage, among other things. Journal of the Royal Anthropological Institute (N.S.) 14, 717-35.

Lambeк, M. 2011. Kinship as gift and theft: acts of succession in Mayotte and Ancient Israel. American Ethnologist 38, 2-16.

Landolt, P. \& W.-W. DA 2005. The spatially ruptured practices of migrant families. Current Sociology 53, 625-53.

LeVitt, P. \& N. Glick SChiller 2004. Conceptualizing simultaneity: a transnational social field perspective on society. International Migration Review 38, 1002-40.

Liu, H.-C. 1959. The traditional Chinese clan rules. New York: J.J. Augustin.

Menjivar, C. 2012. Transnational parenting and immigration law: Central Americans in the United States. Journal of Ethnic and Migration Studies 38, 301-22.

Mitchell, C. 1969. Social networks in urban situations: analyses of personal relationships in Central African towns. Manchester: University Press.

Moench, R.U. 1963. Economic relations of the Chinese in the Society Islands. Unpublished Ph.D. thesis, Harvard University.

MorawsKa, E. 2001. Immigrants, transnationalism, and ethnicization: a comparison of this great wave and the last. In E pluribus unum? Contemporary and historical perspectives on immigrant political incorporation (eds) G. Gerstle \& J. Mollenkopf, 175-212. New York: Russell Sage.

Nonini, D.M. 2003. All are flexible, but some are more flexible than others: small-scale Chinese businesses in Malaysia. In Ethnic business: Chinese capitalism in Southeast Asia (eds) K.S. Jomo \& B.C. Folke, 73-91. London: Routledge Curzon.

2005. Toward a (proper) postwar history of Southeast Asian petty capitalism: predation, the state, and Chinese small business capital in Malaysia. In Petty capitalists and globalization: flexibility, entrepreneurship, and economic development (eds) A. Smart \& J. Smart, 167-200. Albany: State University of New York Press.

Nyíri, P. 2002. From class enemies to patriots. In Globalizing Chinese migration (eds) P. Nyíri \& I.R. Saveliev, 208-41. Aldershot, Hants: Ashgate.

Olwig, K.F. 2007. Carribean journeys: an ethnography of migration and home in three family networks. Durham, N.C.: Duke University Press.

OnG, A. 1999. Flexible citizenship: the cultural logics of transnationality. Durham, N.C.: Duke University Press.

\& D.M. Nonini 1997. Introduction: Chinese transnationalism as an alternative modernity. In Ungrounded empires: the cultural politics of modern Chinese transnationalism (eds) A. Ong \& D.M. Nonini, 1-33. New York: Routledge.

Panoff, M. 1991. The French way in plantation systems. The Journal of Pacific History 26, 206-12.

Parreñas, R.S. 2005. Children of global migration: transnational families and gendered woes. Stanford: University Press.

Portes, A., L. Guarnizo \& P. Landolt 1999. Introduction: pitfalls and promise of an emergent research field. Ethnic and Racial Studies 22, 217-38.

RAzy, E. \& V. BABY-Collin (eds) 2011. La famille transnationale dans tous ses états. Autrepart 57-8 (Special Issue).

Rouse, R. 1991. Mexican migration and the social space of postmodernism. Diaspora 1, 8-23.

SAHLins, M. 2013. What kinship is - and is not. Chicago: University Press.

Skinner, G.W. 1957. Chinese society in Thailand: an analytical history. Ithaca, N.Y.: Cornell University Press. Smart, A. \& J. Smart 1998. Transnational social networks and negotiated identities in interactions between Hong Kong and China. In Transnationalism from below (eds) M.P. Smith \& L.E. Guarnizo, 103-61. New Brunswick, N.J.: Transaction Publishers. 
Smith, M.P. \& L.E. Guarnizo (eds) 1998. Transnationalism from below. New Brunswick, N.J.: Transaction Publishers.

STAFFord, C. 2000. Chinese patriliny and the cycles of yang and laiwang. In Cultures of relatedness: new approaches to the study of kinship (ed.) J. Carsten, 35-54. Cambridge: University Press.

Trémon, A.-C. 2007. Fils illégitimes, affiliations conflictuelles: métissage et identité 'demie' en Polynésie française. L'Homme: revue française d'anthropologie 181, 75-100 2009. Cosmopolitanization and localization. Anthropological Theory 9, 103-26.

2010. Chinois en Polynésie française: migration, métissage, diaspora. Nanterre: Société d'ethnologie.

Waldinger, R. \& D. Fitzgerald 2004. Transnationalism in question. American Journal of Sociology 109, 1177-95.

WAng, G. 2000. The Chinese overseas: from earthbound China to the quest for autonomy. Cambridge, Mass.: Harvard University Press.

WAtERs, J. 2005. Transnational family strategies and education in the contemporary Chinese diaspora. Global Networks 5, 359-77.

Watson, J. 1975. Emigration and the Chinese lineage: the Mans in Hong Kong and London. Berkeley: University of California Press.

WoLf, M. 1972. Women and the family in rural Taiwan. Stanford: University Press.

YAN, Y. 1996. The flow of gifts: reciprocity and social networks in a Chinese village. Stanford: University Press.

YANAGisako, S.J. 1975. Two processes of change in Japanese-American kinship. Journal of Anthropological Research 31, 196-224.

1979. Family and household: the analysis of domestic groups. Annual Review of Anthropology 8, 161-205.

\section{Parenté flexible : les familles transnationales des Chinois de Tahiti}

Résumé

Cet article examine les pratiques de "parenté flexible » déployées par les migrants Chinois dans le Tahiti colonial. "Parenté flexible » souligne les emplois stratégiques de la parenté dans un contexte de migration et de diaspora: les ajustements à des frontières culturelles, politiques et juridiques qui mènent à des changements dans les formes familiales et les relations entre parents. Recourant à une perspective multi-générationnelle, l'article examine comment les familles ont été modelées par des changements et retournements de conjonctures politico-légales et économiques sur le long XXe siècle. L'auteure souligne l'importance des pratiques transnationales de traversée des frontières qui n'impliquent pas simplement une extension spatiale des réseaux mais aussi des stratégies juridiques dans le pays d'accueil. Elle montre également que si l'ordre hiérarchique confucéen a conditionné les pratiques transnationales de parenté flexible, cette hiérarchie a été adaptée aux circonstances, voire a été largement altérée. Enfin, l'auteure avance que l'histoire des ajustements familiaux a forgé un habitus qui tend vers la maximisation de la sécurité économique et juridique, en particulier parmi les femmes.

Anne-Christine Trémon is a Senior Lecturer in Anthropology at the Universite de Lausanne. She obtained her Ph.D. at the École des Hautes Études en Sciences Sociales (EHESS) in 2005. Her research examines the Chinese diaspora in a global anthropological and historical perspective.

Université de Lausanne, Quartier UNIL-Mouline, Géopolis 5331, 1015, Lausanne, Switzerland. AnneChristine.Tremon@unil.ch 